\title{
Isplativost rada u Hrvatskoj i Sloveniji: analiza pomoću mikrosimulacijskog modela
}

SLAVKO BEZEREDI *

Institut za javne financije

Zagreb, Hrvatska
Izvorni znanstveni rad

UDK: 331.101(497.4)(497.5)

doi: $10.3935 /$ rsp.v28i2.1787

Primljeno: prosinac 2020.

U radu se analizira utjecaj poreza $i$ socijalnih naknada na isplativost rada u Hrvatskoj i Sloveniji. Promatraju se neaktivne i nezaposlene osobe i njihov hipotetski prelazak u zaposlenost, a kao glavni pokazatelj isplativosti rada izračunava se participacijska porezna stopa (PPS), koja mjeri koliki će dio bruto plaće ostvarene na novom poslu biti izgubljen iz proračuna kućanstava zbog povećanja iznosa plaćenih poreza $i$ smanjenja iznosa primljenih socijalnih naknada. Za razliku od ranijih istraživanja, koja su za obje zemlje napravljena na hipotetskim podatcima, $u$ ovom se radu po prvi put izračuni $i$ analiza PPS-a zasnivaju na anketnim podatcima, čime se za obje zemlje dobiva realna slika stanja na području isplativosti rada. Analiza je provedena na podatcima i sustavu poreza i socijalnih naknada za 2017., a glavni alat koji se koristi je EUROMOD - mikrosimulacijski model poreza i socijalnih naknada za zemlje EU-a. Rezultati pokazuju da je prosječni PPS u Hrvatskoj umjerene veličine od 31,3\%, a Slovenija ima za 11,3 postotnih bodova veći PPS. Visok PPS u obje zemlje će s većom vjerojatnošću imati osobe s većim brojem maloljetne djece $i$ osobe s nižom razinom tržišnog dohotka ostalih članova kućanstva, a u Hrvatskoj će to imati i osobe koje imaju samo osnovnoškolsko obrazovanje.

Ključne riječi: participacijska porezna stopa, isplativost rada, EUROMOD, Hrvatska, Slovenija.

\section{UVOD}

Glavna namjena socijalnih naknada je osigurati prihvatljiv životni standard za kućanstva koja nisu u mogućnosti ostvariti dohodak iz drugih izvora. Budući da djeluju kao mjere protiv siromaštva, socijalne naknade smanjuju razlike u dohotku na dnu dohodovnog spektra te predstavljaju važnu ulogu u politici preraspodjele (Immervoll, 2009.). Jednako tako, socijalne naknade pružaju određenu materijalnu sigurnost osobama s niskim primanjima i pomažu im u postizanju ravnomjernije razine dohotka tijekom vremena.

Međutim, visoki iznosi naknada koje primaju osobe izvan rada mogu rad učiniti manje privlačnim i tako utjecati na smanjenje poticaja za prihvaćanje zaposlenja, što je posebno izraženo u slučaju kada se osoba može zaposliti samo na niskim razinama bruto plaće. Za takve osobe iznos socijalnih naknada u stanju kada ne rade

\footnotetext{
* Slavko Bezeredi, Institut za javne financije / Institute of Public Finance, Smičiklasova 21, 10000 Zagreb, Hrvatska / Croatia, slavko.bezeredi@ijf.hr
} 
gotovo je jednak neto dohotku koji bi te osobe mogle ostvariti kada bi se zaposlile. Spomenute osobe nemaju gotovo nikakve financijske poticaje za prihvaćanje zaposlenja te upadaju u zamku nezaposlenosti ili neaktivnosti.

Uz socijalne naknade, porezno opterećenje rada također utječe na financijske poticaje za zapošljavanje. Porezno opterećenje rada stvara klin između ukupnih troškova rada koje plaća poslodavac i realne neto plaće koju prima zaposlenik. Na strani potražnje za radom, visoki iznosi poreznog tereta utječu na ukupne troškove rada, a na strani ponude, visoki porezni teret utječe na smanjenje poticaja za povećanje radnih sati zaposlenih osoba (Immervoll i O'Donoghue, 2002.) ili na smanjenje poticaja za prihvaćanje posla s plaćama na donjem kraju ljestvice plaća (Carone i sur., 2009.).

U ovom radu analizira se utjecaj poreza $i$ socijalnih naknada na isplativost rada $\mathrm{u} \mathrm{Hr}-$ vatskoj i Sloveniji u 2017. na temelju anketnih (stvarnih) podataka. Predmet istraživanja su neaktivne i nezaposlene osobe, ${ }^{1} \mathrm{a}$ analizira se njihov hipotetski prelazak u svijet rada. Kao glavni pokazatelj isplativosti rada, izračunava se participacijska porezna stopa (engl. participation tax rate; PPS), koja mjeri koliki će dio bruto plaće ostvarene na novom poslu biti izgubljen iz proračuna kućanstava zbog povećanja iznosa plaćenih poreza i smanjenja iznosa primljenih socijalnih naknada. Za procjenu PPS-a koristi se EUROMOD, mikrosimulacijski model poreza i socijalnih naknada za zemlje Europske unije, koji služi za procjenu utjecaja izravnih poreza, doprinosa za socijalno osiguranje i socijalnih naknada na raspoloživi dohodak kućanstva $\mathrm{i}$ isplativost rada te omogućuje usporedbu između zemalja EU-a. Glavna prednost EUROMOD-a je što uključuje module za sve zemlje EU-a unutar istog metodološkog okvira što omogućuje fleksibilnost analize i usporedivost rezultata (Sutherland i Figari, 2013.). Koriste se hrvatski i slovenski modul EUROMOD-a, koji se zasnivaju na pravilima hrvatskog i slovenskog sustava poreza i socijalnih naknada za 2017. godinu. Podatci su dobiveni iz ankete EU-SILC (engl. Statistics on Income and Living Conditions) za 2018., pri čemu se dohodovne varijable iz ankete odnose na 2017.

U Hrvatskoj se područje isplativosti rada tek nedavno počelo konkretnije istraživati. Bejaković i sur. (2012.) i Bezeredi (2019.) izračunali su PPS za odabrane tipove hipotetskih kućanstava. Za Sloveniju, kao i za Hrvatsku, postoje samo analize isplativosti rada na temelju hipotetskih podataka, koje su proveli Dolenc i Vodopivec (2005.) i Laporšek, Vodopivec i Vodopivec (2019.). Iako takve analize mogu ukazati na problem visokog PPS-a za pojedine tipove kućanstava, izračuni na hipotetskim podacima ne daju pravu sliku stanja u nekoj zemlji. Hipotetski primjeri mogu otkriti koji tipovi kućanstava imaju visok PPS, ali ne otkrivaju koliko ima takvih kućanstava, odnosno ne otkrivaju je li visok PPS doista ozbiljan problem u Hrvatskoj i Sloveniji te koliko će biti »dobitnika« ili »gubitnika« uslijed provedbe neke reforme sustava poreza i socijalnih naknada. ${ }^{2}$ Spomenute odgovore moguće je dobiti upotrebom reprezentativnih mikropodataka (Carone i sur., 2004.), a to je ujedno i glavna prednost korištenja anketnih u odnosu na hipotetske podatke.

\footnotetext{
${ }^{1}$ Pod neaktivnim osobama u ovoj analizi smatraju se osobe koje obavljaju kućanske poslove i brinu se o kućanstvu. Ostale skupine koje se ponekad nazivaju neaktivnima (osobe u obrazovanju, umirovljenici, nesposobni za rad, itd.) nisu predmet ove analize.

${ }^{2}$ Osim spomenutih nedostataka, analize na hipotetskim podatcima imaju i svojih prednosti. Neke od prednosti su da rezultati ne ovise o obliku populacijske strukture, te je moguće utvrditi kako će određena reforma utjecati točno na određeni tip kućanstva (Gasior i Recchia, 2020.). Nadalje, hipotetske analize mogu biti pogodne i za komparativna istraživanja u kojima se utvrđuju različitosti između poreznih i socijalnih sustava određenih zemalja (Immervoll, Marianna i D’Ercole, 2004.).
} 
Znanstveni doprinos ovog istraživanja je višestruk. Budući da se u istraživanju koriste stvarni podatci, znanstveni doprinos očituje se u dobivanju novih spoznaja o isplativosti rada na stvarnim (anketnim) podacima u Hrvatskoj i Sloveniji, čime se otkriva prava slika stanja u tim zemljama, što je prvo takvo istraživanje. Stječu se spoznaje o tome koje »specifične grupe« ljudi izvan rada u Hrvatskoj i Sloveniji (npr. osobe s nižim stupnjem obrazovanja, osobe s više djece, itd.) imaju slabe poticaje za prihvaćanje zaposlenja. Analizira se dekompozicija PPS-a prema odabranim elementima poreznog i socijalnog sustava te se otkriva koje sastavnice tih sustava najviše utječu na visinu PPS-a u tim zemljama. Konačno, istraživanje također daje doprinos u području komparativne analize stanja na području isplativosti rada između Hrvatske i Slovenije.

Rad je strukturiran na sljedeći način. Nakon uvoda, u drugom dijelu opisan je kratki pregled literature na području isplativosti rada, a u trećem dijelu opisana je metodologija istraživanja i korišteni podatci. $\mathrm{U}$ četvrtom dijelu prezentiraju se rezultati istraživanja. Analizira se stanje na području isplativosti rada u obje zemlje, napravljena je kratka komparativna analiza rezultata između Hrvatske i Slovenije, te se na koncu poglavlja dobiveni rezultati uspoređuju s rezultatima prethodnih istraživanja provedenih na hipotetskim podatcima. U petom dijelu slijedi zaključak.

\section{ISPLATIVOST RADA NA EKSTENZIVNOJ GRANICI PONUDE RADA: KRATKI PREGLED DOSADAŠNJIH ISTRAŽIVANJA}

Participacijska porezna stopa (PPS) mjeri financijske poticaje za rad na ek- stenzivnoj granici ponude rada, na kojoj se mjere financijski poticaji prelaska trenutno nezaposlenih ili neaktivnih osoba u stanje zaposlenosti. Uz ekstenzivnu granicu, u literaturi se spominje i intenzivna granica ponude rada, na kojoj se mjere financijski poticaji trenutno zaposlenih osoba za povećanjem radnih sati, kako bi zaradile veće iznose bruto plaće. ${ }^{3}$ Međutim, kako su u fokusu ovog istraživanja samo nezaposlene i neaktivne osobe i njihov hipotetski prelazak u stanje zaposlenosti, naglasak će biti na istraživanjima poticaja za rad na ekstenzivnoj granici ponude rada.

Prvo istraživanje isplativosti rada u $\mathrm{Hr}-$ vatskoj proveli su Bejaković i sur. (2012.). Analiza je napravljena za 2011. na temelju hipotetskih podataka i utvrdilo se da u Hrvatskoj postoje tipovi kućanstava s vrlo visokim PPS-om. Pokazalo se da visok PPS prilikom prelaska iz neaktivnosti u zaposlenost uz minimalnu bruto plaću imaju samohrani roditelji s dvoje djece $(91 \%)$ i parovi s dvoje djece u kojima prvi supružnik razmatra zaposlenje, a drugi ne radi (98\%). Dakle, to su kućanstva s djecom koja u situaciji kada niti jedan odrasli član ne radi mogu ostvariti relativno visoke iznose socijalnih naknada. Spomenute nalaze potvrdio je i Bezeredi (2019.) koji je na hipotetskim podatcima istraživao PPS u Hrvatskoj u 2018., a napravljena je i komparativna analiza PPS-a u zemljama EU-a koja je pokazala da se za spomenute tipove kućanstva Hrvatska nalazi među zemljama s najvišim PPS-om. Za samohranog roditelja s dvoje djece koji se zapošljava uz pola bruto plaće, PPS u Hrvatskoj iznosio je $87 \%$, a jedino su Danska (92\%) i Austrija (93\%) imale PPS veći od Hrvatske, dok je u Sloveniji PPS iznosio $81 \%$. Što se tiče parova s dvoje djece u kojima se prvi supružnik zapošljava uz pola bruto plaće, a drugi ne radi, najveći

\footnotetext{
${ }^{3}$ Neki od radova u kojima se analiziraju poticaji za rad na ekstenzivnoj i intenzivnoj granici ponude rada su Saez (2002.), Adam i Browne (2010.), Blundell, Bozio i Laroque (2013.), Ranđelović i Žarković Rakić (2013.), Jara, Gasior i Makovec (2019.).
} 
PPS imale su Austrija i Švedska u kojima je PPS iznosio $100 \%$, a u Hrvatskoj i Sloveniji je redom iznosio $83 \%$ i $80 \%$.

Laporšek, Vodopivec i Vodopivec (2019.) su u istraživanju PPS-a na hipotetskim podatcima za Sloveniju u 2016. također pokazali da isti tipovi kućanstava imaju vrlo visok PPS. U istom istraživanju napravljena je i komparativna analiza PPS-a u zemljama EU-a i OECD-a koja je pokazala da se za te tipove kućanstava Slovenija i Hrvatska nalaze među polovicom zemalja OECD-a i EU-a s višim iznosom PPS-a. Dolenc i Vodopivec (2005.) zaključuju da u 2002. vrlo visok PPS u Sloveniji imaju osobe koje žive u kućanstvima s većim brojem uzdržavanih članova i koje prilikom zaposlenja mogu ostvariti primanja iz donjeg dijela distribucije bruto plaće. Carone i sur. (2004.) su analizom hipotetskih kućanstava za zemlje OECD-a utvrdili da je vjerojatnost upadanja u zamku neaktivnosti veća za osobe s nižim stupnjem obrazovanja, koje mogu ostvariti samo niske iznose bruto plaće, što takvu skupinu ljudi čini marginalnom skupinom na tržištu rada.

Kao primjer različitih pristupa istraživanju PPS-a valja istaknuti i sljedeće radove. Myck i sur. (2015.) su na slučaju Poljske istraživali utjecaj provedenih reformi socijalnog i poreznog sustava i znatnog rasta realnih plaća na isplativost rada u razdoblju od 2005. do 2011. Rezultati pokazuju da, unatoč značajnim poreznim olakšicama koje su uvedene u promatranom razdoblju, financijski poticaji za rad postaju slabiji za kućanstva s djecom i za ona koja imaju pravo na socijalne naknade. Međutim, unatoč spomenutim negativnim učincima na isplativost rada određenih skupina kućanstava, ukupni rezultati pokazuju da se zbog značajnog rasta realne plaće tijekom promatranog razdoblja značajno poboljšavaju i financijski poticaji za rad. Navicke i Lazutka (2016.) istraživali su isplativost rada u Litvi na intenzivnoj granici ponude rada korištenjem anketnih podataka i na eksten- zivnoj granici koristeći hipotetske podatke. Analiza na intenzivnoj granici ponude rada pokazuje da su financijski poticaji za rad relativno visoki na srednjem i gornjem dijelu distribucije dohotka, dok su oni značajno niži za osobe koje se nalaze u nižim kvintilima ekvivalentnog raspoloživog dohotka. Jako niski poticaji za rad osoba koje se nalaze na dnu dohodovne distribucije rezultat su dominantnog utjecaja novčanih socijalnih naknada, dok učinak poreza na dohodak i doprinosa iz plaće nije posebice izražen. Analiza hipotetskih kućanstava na ekstenzivnoj granici ponude rada pokazala je da su samohrani roditelji i kućanstva s djecom u kojima se prvi odrasli član zapošljava, a drugi ne radi najviše izloženi zamkama nezaposlenosti i neaktivnosti. Autori tvrde da su takve obitelji ujedno i najosjetljivije na nagle promjene visine socijalnih naknada u odnosu na plaće.

Galuščák i Pavel (2012.) analizirali su financijske poticaje za rad na ekstenzivnoj granici ponude rada za određene tipove kućanstava na temelju sustava poreza i socijalnih naknada iz 2006. u Češkoj. Pokazali su da niže financijske poticaje za rad imaju kućanstva s nižim primanjima i kućanstva s djecom i supružnikom koji ne radi. Navode kako na isplativost rada na ekstenzivnoj granici utječe dostupnost i iznosi naknada, od kojih se ističu naknada za nezaposlene $\mathrm{i}$ socijalna pomoć. Dušek, Kalíšková i Münich (2013.) su na temelju anketnih podataka iz EU-SILC istraživanja za Češku za 2011. procijenili empirijske poticaje za rad na intenzivnoj i ekstenzivnoj granici ponude rada. Istraživanje na intenzivnoj granici ponude rada u Češkoj pokazalo je da oko $77 \%$ zaposlenih i samozaposlenih ima graničnu efektivnu poreznu stopu veću od $45 \%$ što je, gledajući međunarodnu usporedbu, jedan od najviših iznosa. Na ekstenzivnoj granici ponude rada procijenili su PPS za prelazak nezaposlenih i neaktivnih osoba u zaposlenost, ali su napravili i procjene PPS-a za suprotnu situaciju u kojoj bi trenut- 
no zaposlene ili samozaposlene osobe ostale bez posla. Rezultati sugeriraju da postoji značajan udio osoba s visokim PPS-om, pri čemu PPS veći od $60 \%$ ima $8 \%$ neaktivnih ili nezaposlenih osoba i $11 \%$ zaposlenih i samozaposlenih osoba (Dušek, Kalíšková i Münich, 2013.).

\section{METODOLOGIJA ISTRAŽIVANJA I PODATCI}

\section{Podatci i EUROMOD}

Mikrosimulacijskim modelima poreza i socijalnih naknada simuliraju se iznosi doprinosa, poreza i socijalnih naknada na razini pojedinaca i kućanstava. U ovom radu koriste se hrvatski i slovenski modul EUROMOD-a, zasnovani na pravilima sustava poreza i socijalnih naknada koja su vrijedila 30. lipnja 2017. Jedna od glavnih prednosti EUROMOD-a je što na temelju istog metodološkog obrasca obuhvaća sve zemlje EU-a i tako omogućuje fleksibilnost analize i komparativnu analizu rezultata (Sutherland i Figari, 2013.).

EUROMOD je nebihevioralni (statički) mikrosimulacijski model, što znači da se pretpostavlja kako reforme poreza i socijalnih naknada ne utječu na ponašanje pojedinaca na tržištu rada te da se sociodemografska obilježja populacije ne mijenjaju kroz vrijeme. ${ }^{4}$ Koristeći bazu reprezentativnih mikropodataka za svaku zemlju EU-a, EUROMOD omogućava komparativne izračune aritmetičkih, odnosno nebihevioralnih učinaka poreza i socijalnih naknada na raspoloživi dohodak pojedinaca i kućanstava za sve zemlje EU-a, kao i za EU u cjelini. Dodatno, omogućuje analizu utjecaja reformi sustava poreza i socijal- nih naknada na (i) distribuciju dohotka, (ii) isplativost rada i (iii) državni proračun svake zemlje EU-a. Također, EUROMOD otkriva kako različite politike u različitim zemljama mogu pridonijeti specifičnim ili zajedničkim ciljevima zemalja kroz (i) usporedbu specifičnih instrumenata sustava poreza i socijalnih naknada među zemljama, (ii) zamjenu određene politike ili cijelog sustava poreza i socijalnih naknada i (iii) analizu utjecaja zajedničkih promjena među zemljama (Lietz i Mantovani, 2007.; Sutherland i Figari, 2013.). Također, valja napomenuti kako su iznosi pojedinih instrumenata sustava poreza i socijalnih naknada koje nije bilo moguće simulirati u modelu uzeti izravno iz anketnih podataka (Jara i Tumino, 2013.).

Za obje zemlje koriste se podatci iz ankete EU-SILC 2018 (engl. Statistics on Income and Living Conditions), koja je provedena u 2018. godini. EU-SILC je obvezno istraživanje koje za sve zemlje EU-a omogućuje komparativnu analizu statistike dohotka, pokazatelja siromaštva i socijalne isključenosti. Anketa se provodi na godišnjoj periodici koristeći rotirajući panelni uzorak slučajno odabranih privatnih kućanstava. Prikupljeni uzorak ponderira se na način da se svakoj osobi iz uzorka dodjeljuje odgovarajući ponder, čime se uzorak projicira na cjelokupnu populaciju.

Anketa sadrži podatke o bruto i neto dohotku cjelokupnog kućanstva i svakog pojedinog člana kućanstva. Podatci o dohotku podijeljeni su u više kategorija: podatci o dohotku koji se ostvaruje na tržištu rada (npr. dohodak od zaposlenosti, samozaposlenosti i ugovora o djelu), dohotku koji se ne ostvaruje izravno na tržištu rada (npr.

\footnotetext{
${ }^{4}$ Statički izračuni prikazuju trenutne učinke provedenih reformi, odnosno procjenjuju se učinci koji bi se dogodili odmah po uvođenju reformi bez da se u obzir uzmu potencijalne reakcije pojedinaca na uvedene reforme. Statički izračuni koje provodi EUROMOD mogu se koristiti kao osnova za druge sofisticiranije ekonomske modele kojima je cilj analizirati učinke određenih reformi ili sociodemografskih promjena na ponašanje pojedinaca ili na makroekonomske pokazatelje (Sutherland i Figari, 2013.). Na primjer, EUROMOD se u literaturi često koristi kao osnova za modele ponude rada, kao primjer vidjeti radove Bargain i Orsini (2006) i Bezeredi i sur. (2019.).
} 
dohodak od kapitala i imovine), dohotku od različitih socijalnih naknada (npr. naknade socijalne pomoći i naknade iz socijalnog osiguranja) i privatnim transferima (npr. alimentacija). Nadalje, anketni podaci sadrže informacije o stupnju obrazovanja osoba, statusu aktivnosti i zaposlenosti, materijalnom i financijskome statusu kućanstva te informacije o zdravstvenom stanju (na temelju osobne procjene ispitanika), ali i mnogim drugim demografskim i socioekonomskim obilježjima osoba i kućanstava (DZS, 2017.). Referentno razdoblje za podatke o dohotku je prethodna kalendarska godina, tako da se u ovom istraživanju sve varijable o dohotku odnose na 2017.

\section{Izračun indikatora isplativosti rada - participacijska porezna stopa}

Kako bi se izmjerili poticaji za rad prilikom prelaska neaktivnih i nezaposlenih osoba u zaposlenost, kao glavni pokazatelj isplativosti rada koristi se participacijska porezna stopa (PPS). PPS mjeri koliki se udio bruto plaće gubi prilikom prelaska promatrane osobe iz stanja nezaposlenosti ili neaktivnosti u zaposlenost zbog toga što se povećavaju porezi i smanjuju socijalne naknade (Jara, Gasior i Makovec, 2019.). Za svaku neaktivnu i nezaposlenu osobu PPS se računa na sljedeći način:

$$
P P S_{i}=1-\frac{Y_{i}^{1}-Y_{i}^{0}}{X_{i}^{1}-X_{i}^{0}}
$$

Gdje $Y_{i}^{0}$ označava raspoloživi dohodak kućanstva promatrane osobe $i$ u stanju kada nije zaposlena (što odgovara stvarnom stanju). $Y_{i}^{1}$ predstavlja raspoloživi dohodak kućanstva kada se osoba $i$ nalazi u hipotetskom stanju zaposlenosti. Bruto plaća osobe $i$ u hipotetskom stanju zaposlenosti označena je s $X_{i}^{1}$, a $X_{i}^{0}$ predstavlja bruto plaću osobe $i$ u stanju kada nije zaposlena $\left(X_{i}^{0}=0\right)$.

Pretpostavlja se da se nezaposlene i neaktivne osobe zapošljavaju na puno radno vrijeme. Simulacija se vrši na sljedeći način. U prvom koraku se pomoću EUROMOD-a izračunavaju iznosi poreza, socijalnih naknada i raspoloživog dohotka u stvarnom stanju, odnosno u stanju u kojem su promatrane osobe izvan zaposlenosti. U drugom koraku se izračuni ponavljaju za hipotetsko stanje u kojem su promatrane osobe zaposlene. Kako plaće za neaktivne i nezaposlene osobe nisu dostupne $u$ podatcima, potrebno ih je predvidjeti. Za predviđanje bruto place $X_{i}^{1}$ u hipotetskom stanju zaposlenosti koristi se Heckmanov selekcijski model koji identificira i uklanja problem odabira uzorka (engl. sample selection problem) i koji istraživači uobičajeno koriste za predviđanje plaća osoba izvan rada. ${ }^{5}$ Rezultati modela za obje zemlje i kratki opis korištenih varijabli dani su u dodatku D1. Nadalje, kada u istom kućanstvu postoje dvije ili više neaktivnih ili nezaposlenih osoba, PPS se zasebno računa za svaku takvu osobu, zadržavajući pritom nepromijenjenima sva obilježja ostalih članova kućanstva.

Kako bi se otkrio utjecaj svake komponente poreznoga i socijalnog sustava na isplativost rada, potrebno je napraviti dekompoziciju PPS-a. Raspoloživi dohodak kućanstva može se izraziti pomoću izvornog dohotka (ukupnog dohotka prije poreza i naknada; oznaka $O$ ), socijalnih naknada $(B)$, poreza $(T)$ i doprinosa iz plaće $(D)$, pa se jednakost (1) može dekomponirati na sljedeći način (Jara, Gasior i Makovec, 2019.)

$$
P P S_{i}=1-\frac{\left(O_{i}^{1}-O_{i}^{0}\right)+\left(B_{i}^{1}-B_{i}^{0}\right)-\left(T_{i}^{1}-T_{i}^{0}\right)-\left(D_{i}^{1}-D_{i}^{0}\right)}{X_{i}^{1}-X_{i}^{0}}
$$

\footnotetext{
${ }^{5}$ Više o Heckmanovom selekcijskom modelu vidjeti u radovima Heckman (1976.) i Heckman (1979.). Dodatno, kao primjer radova u kojima za predviđanje plaća osoba izvan rada koristi Heckmanov selekcijski model vidjeti Bargain i Orsini (2006.), Bargain i sur. (2010.), O’Donoghue (2011.), Bezeredi i Urban (2016.) itd.
} 
Budući da je promjena izvornog dohotka, $\left(O_{i}^{1}-O_{i}^{0}\right)$, jednaka promjeni bruto dohotka, $\left(X_{i}^{1}-X_{i}^{0}\right)$, izraz (2) poprima sljedeći oblik

$$
\begin{aligned}
P P S_{i} & =-\frac{\left(B_{i}^{1}-B_{i}^{0}\right)-\left(T_{i}^{1}-T_{i}^{0}\right)-\left(D_{i}^{1}-D_{i}^{0}\right)}{X_{i}^{1}-X_{i}^{0}}= \\
& =\frac{\left(B_{i}^{0}-B_{i}^{1}\right)}{X_{i}^{1}-X_{i}^{0}}+\frac{\left(T_{i}^{1}-T_{i}^{0}\right)}{X_{i}^{1}-X_{i}^{0}}+\frac{\left(D_{i}^{1}-D_{i}^{0}\right)}{X_{i}^{1}-X_{i}^{0}}= \\
& =P P S_{i}^{B}+P P S_{i}^{T}+P P S_{i}^{D} .
\end{aligned}
$$

Komponenta $P P S_{i}^{B}$ mjeri doprinos socijalnih naknada u ukupnom PPS-u, odnosno promjenu iznosa socijalnih naknada na razini kućanstva izraženu kao postotak promjene bruto dohotka do koje dolazi prilikom prelaska iz stanja nezaposlenosti ili neaktivnosti u zaposlenost. Komponente $P P S_{i}^{B}$ i $P P S_{i}^{T}$ mjere doprinos poreza na dohodak i doprinosa iz plaće ukupnom PPS-u.

\section{REZULTATI}

U ovom dijelu analiziraju se rezultati istraživanja u području isplativosti rada u Hrvatskoj i Sloveniji u 2017., a napravljena je i komparativna analiza rezultata između Hrvatske i Slovenije.

\section{Struktura populacije za procjenu isplativosti rada u Hrvatskoj i Sloveniji}

U svrhu istraživanja isplativosti rada najprije se definiraju »fleksibilne« osobe, a to su žene u dobi od 18 do 60 i muškarci u dobi od 18 do 65 godina koji su tijekom 12 mjeseci u godini bili u jednom od sljedeća tri stanja: zaposleni, nezaposleni ${ }^{6}$ ili neaktivni ${ }^{7}$. Fleksibilne osobe ne moraju nužno biti samo u jednom od spomenuta tri stanja tijekom cijele godine, nego mogu prelaziti u bilo koje od ta tri stanja. Međutim, ako je osoba barem jedan mjesec provela u nekom drugom stanju (umirovljenik, student, itd.), takva osoba smatra se nefleksibilnom. Dodatno, sve žene s djecom do navršene prve godine života smatraju se nefleksibilnima. Za fleksibilne osobe smatra se da su zaposlene ako rade više od 5 sati tjedno, a ostale fleksibilne osobe smatraju se nezaposlenim ili neaktivnim i za njih se procjenjuju poticaji za rad na ekstenzivnoj granici ponude rada. ${ }^{8}$

Tablica 1. analizira strukturu prethodno definirane populacije u Hrvatskoj i Sloveniji na temelju ankete EU-SILC 2018. Deskriptivna analiza pokazuje da u Hrvatskoj postoji 2,4 milijuna žena u dobi od 18 do 60 i muškaraca u dobi 18 do 65 godina, od čega je 1,7 milijuna, odnosno $72 \%$, fleksibilnih osoba, a ostale osobe su nefleksibilne. Nadalje, 1,4 milijuna fleksibilnih osoba u Hrvatskoj je zaposleno, a preostalih 363 tisuće fleksibilnih osoba je nezaposleno ili neaktivno. Slovenija ima 1,2 milijuna žena u dobi od 18 do 60 i muškaraca u dobi 18 do 65 godina. Od toga je 842 tisuće fleksibilnih osoba, a 360 tisuća ih je nefleksibilno. Prema statusu zaposlenosti fleksibilnih osoba u Sloveniji, 758 tisuća ih je zaposleno, a 84 tisuća ih je nezaposleno ili neaktivno.

${ }^{6}$ U Hrvatskoj je u 2017. broj nezaposlenih prema SILC anketi bio za čak $91 \%$ veći od broja dobivenog na temelju Ankete o radnoj snazi (ARS) (Urban, Bezeredi i Pezer, 2020.). U SILC-u se ekonomski status zasniva na odgovorima ispitanika, pa ne mora nužno biti u skladu s ARS definicijom. Dakle, spomenuta velika razlika u broju nezaposlenih javlja se zbog različitih metodologija između spomenuta dva istraživanja, pri čemu se događa da se veliki broj ARS-neaktivnih osoba prijavi kao nezaposleni u SILC-u. U Sloveniji također postoje odstupanja, u 2017. je broj nezaposlenih prema SILC anketi bio za $68 \%$ veći od broja objavljenog od strane Statističkog ureda Republike Slovenije (Kump i sur., 2020.).

${ }^{7}$ Definiciju neaktivnih osoba vidjeti u fusnoti 1.

${ }^{8}$ Pojam »fleksibilnih osoba« definira se u radu Bezeredi i sur. (2019.), a označava uzorak osoba koje se uobičajeno analiziraju u literaturi o isplativosti rada. Uz određene modificirane kriterije odabira fleksibilnih osoba koje se odnose na dob osoba, u ovom radu su fleksibilne osobe definirane prema uzoru na rad Bezeredi i sur. (2019.). 
Tablica 1.

Fleksibilne i nefleksibilne osobe u Hrvatskoj i Sloveniji

\begin{tabular}{lrrrc}
\hline & \multicolumn{2}{c}{$\begin{array}{c}\text { Udio u ukupnoj populaciji } \\
\text { žena u dobi 18-60 i }\end{array}$} \\
& Hrvatska & Slovenija & Hrvatska & Slovenija \\
\hline $\begin{array}{l}\text { Žene u dobi 18-60 i } \\
\text { muškarci u dobi 18-65 }\end{array}$ & 2395136 & 1201543 & 100 & 100 \\
\hline Nefleksibilne osobe & 665845 & 359611 & 27,8 & 29,9 \\
\hline Fleksibilne osobe & 1729291 & 841932 & 72,2 & 70,1 \\
\hline Fleksibilne zaposlene osobe & 1366490 & 758055 & 57,1 & 63,1 \\
\hline Fleksibilne nezaposlene ili neaktivne osobe & 362801 & 83877 & 15,1 & 7,0 \\
\hline
\end{tabular}

Izvor: Autorovi izračuni na temelju podataka EU-SILC 2018.

Usporedba Hrvatske i Slovenije sugerira da u obje zemlje postoji gotovo jednak udio fleksibilnih osoba u ukupnoj populaciji žena u dobi 18-60 i muškaraca u dobi 18-65. Taj udio u Hrvatskoj iznosi $72 \%$, a u Sloveniji $70 \%$. S druge strane, Slovenija ima upola manji udio nezaposlenih i neaktivnih fleksibilnih osoba u ukupnoj populaciji žena u dobi 18-60 i muškaraca u dobi 18-65, koji iznosi 7\%, dok taj udio u Hrvatskoj iznosi $15 \%$.

\section{Isplativost rada u Hrvatskoj}

U ovom dijelu se na temelju anketnih podataka analizira utjecaj poreza i socijalnih naknada na isplativost rada u Hrvatskoj. U obzir su uzete najvažnije socijalne naknade koje dodjeljuje središnja država: naknada za nezaposlene, zajamčena minimalna naknada (ZMN) i doplatak za djecu. Također se razmatra naknada za troškove stanovanja koja se dodjeljuje na lokalnoj razini i za koju se u ovom radu pretpostavlja da se u cijeloj Hrvatskoj dodjeljuje prema pravilima iz Grada Zagreba. Na strani obveznih davanja u obzir se uzimaju doprinosi iz plaće te porez na dohodak i prirez. Detaljan opis glavnih obilježja spomenutih poreza i socijalnih naknada može se pronaći u izvje- štaju EUROMOD Country Report, Croatia 2017-2020 (Urban, Bezeredi i Pezer, 2020.).

Analizira se kretanje PPS-a neaktivnih i nezaposlenih osoba prema određenim demografskim, socioekonomskim i regionalnim obilježjima, a potom je napravljena i dekompozicija PPS-a kako bi se utvrdilo koji elementi sustava poreza i socijalnih naknada najviše doprinose ukupnom PPS-u. Analiziraju se neaktivne i nezaposlene osobe, koje čine $15 \%$ radno sposobne populacije (žena u dobi 18-60 i muškaraca u dobi 18-65).

Tablica 2. pokazuje da prosječni PPS za neaktivne i nezaposlene osobe u Hrvatskoj iznosi $31,3 \%$, pri čemu 5,9\% promatranih osoba ima PPS između 50 i 70\%, a 2,8\% osoba ima PPS iznad 70\%. Dakle, ukupni PPS u Hrvatskoj umjerene je veličine sa značajnim postotkom osoba s visokim i vrlo visokim PPS-om. ${ }^{9}$

Što se tiče distribucije PPS-a prema dobi, pokazuje se da najveći prosječni PPS od 32,2\% imaju osobe srednje dobi (31-50 godina), što je za 1,2 postotnih bodova više od prosjeka za osobe starije dobi (51-65 godina) i za oko 2,4 postotnih bodova više od prosjeka za osobe mlađe dobi (18-30 godina). Također, osobe srednje dobi imaju veći

${ }^{9}$ PPS ispod 50\% smatra se umjerenim, između 50 i $70 \%$ visokim, dok se PPS veći ili jednak $70 \%$ smatra vrlo visokim. 
udio osoba s vrlo visokim PPS-om nego ostali. Nadalje, pokazuje se da žene imaju veći PPS od muškaraca; PPS za žene iznosi $32,1 \%$, a za muškarce $30,1 \%$. Žene imaju više nego duplo veći udio osoba s vrlo visokim PPS-om - njih 3,6\%, dok 1,6\% muškaraca ima vrlo visok PPS. Dodatno, postoji i više neaktivnih i nezaposlenih žena nego muškaraca, oko 230 tisuća žena naprama 139 tisuća muškaraca.

Osobe s osnovnim stupnjem obrazovanja imaju puno veći PPS $(46,8 \%)$ od osoba sa srednjim $(30,8 \%)$ i višim/visokim $(31,9 \%)$ stupnjem obrazovanja. Također, $12,2 \%$ osoba s osnovnim stupnjem obrazovanja ima vrlo visok PPS, dok taj udio opada sa stupnjem obrazovanja, pa 2,9\% osoba sa srednjim i $0,2 \%$ osoba s višim/visokim stupnjem obrazovanja ima vrlo visok PPS. Međutim, osoba s osnovnim stupnjem obrazovanja ima najmanje, 10 tisuća, dok ih je 322 tisuće sa srednjim i 37 tisuća s višim/visokim obrazovanjem. PPS se gotovo ne mijenja s mjestom stanovanja, a iznosi za sve podskupine su blizu prosječne vrijednosti za cijelu neaktivnu i nezaposlenu populaciju.

Tablica 2.

Distribucija PPS-a prema određenim demografskim i socioekonomskim karakteristikama u Hrvatskoj, u \%

\begin{tabular}{|c|c|c|c|c|c|c|}
\hline & \multirow{2}{*}{$\begin{array}{c}\text { Broj } \\
\text { neaktivnih i } \\
\text { nezaposlenih } \\
\text { osoba (u tis.) }\end{array}$} & \multirow{2}{*}{$\begin{array}{c}\text { Prosječni PPS } \\
\text { (standardna } \\
\text { pogreška) }\end{array}$} & \multicolumn{4}{|c|}{$\begin{array}{c}\text { Distribucija populacije prema razredima } \\
\text { PPS-a }\end{array}$} \\
\hline & & & $<30 \%$ & {$[30 \%, 50 \%>$} & {$[50 \%, 70 \%>$} & $\geq 70 \%$ \\
\hline Ukupno & 363 & $31,3(0,0031)$ & 60,8 & 30,5 & 5,9 & 2,8 \\
\hline \multicolumn{7}{|l|}{ Dob } \\
\hline $18-30$ & 71 & $29,9(0,0068)$ & 64,5 & 26,7 & 7,9 & 0,9 \\
\hline $31-50$ & 169 & $32,2(0,0053)$ & 61,8 & 28,2 & 5,3 & 4,8 \\
\hline $51-65$ & 123 & $31,0(0,0041)$ & 57,4 & 35,9 & 5,5 & 1,3 \\
\hline \multicolumn{7}{|l|}{ Spol } \\
\hline Muško & 137 & $30,1(0,0043)$ & 65,4 & 28,6 & 4,5 & 1,6 \\
\hline Žensko & 226 & $32,1(0,0042)$ & 58,0 & 31,7 & 6,7 & 3,6 \\
\hline \multicolumn{7}{|l|}{ Obrazovanje } \\
\hline Osnovno & 10 & $46,8(0,0263)$ & 27,0 & 30,3 & 30,5 & 12,2 \\
\hline Srednje & 317 & $30,8(0,0033)$ & 63,8 & 27,8 & 5,5 & 2,9 \\
\hline Više/visoko & 36 & $31,9(0,0060)$ & 43,5 & 54,2 & 2,2 & 0,2 \\
\hline \multicolumn{7}{|c|}{ Gustoća naseljenosti } \\
\hline Ruralna područja & 175 & $31,4(0,0045)$ & 62,8 & 27,6 & 5,9 & 3,7 \\
\hline $\begin{array}{l}\text { Srednje naseljena } \\
\text { područja }\end{array}$ & 107 & $31,0(0,0055)$ & 62,7 & 29,2 & 5,8 & 2,3 \\
\hline Urbana područja & 81 & $31,6(0,0064)$ & 54,0 & 38,6 & 5,9 & 1,6 \\
\hline \multicolumn{7}{|l|}{ Broj djece } \\
\hline Nema djece & 209 & $29,5(0,0033)$ & 62,0 & 32,8 & 3,8 & 1,4 \\
\hline Jedno dijete & 72 & $31,3(0,0067)$ & 62,2 & 30,7 & 4,6 & 2,4 \\
\hline Dva djeteta & 49 & $31,7(0,0086)$ & 62,6 & 26,4 & 8,1 & 2,9 \\
\hline Troje ili više djece & 33 & $42,1(0,0168)$ & 47,5 & 21,8 & 18,1 & 12,6 \\
\hline \multicolumn{7}{|c|}{ Tržišni dohodak ostalih članova kućanstva (u tis. kn) } \\
\hline 0 do 0,5 & 41 & $46,7(0,0132)$ & 29,5 & 33,5 & 22,1 & 14,8 \\
\hline 0,5 do 2,5 & 44 & $29,5(0,0094)$ & 75,3 & 14,9 & 5,8 & 4,1 \\
\hline 2,5 do 5 & 57 & $25,4(0,0044)$ & 88,7 & 8,2 & 2,5 & 0,5 \\
\hline 5 do 10 & 110 & $29,3(0,0045)$ & 68,5 & 26,7 & 3,1 & 1,7 \\
\hline više od 10 & 111 & $31,6(0,0041)$ & 44,2 & 50,9 & 4,5 & 0,4 \\
\hline
\end{tabular}

Izvor: Autorovi izračuni koristeći mikrosimulacijski model EUROMOD i podatke EU-SILC 2018. 
Rezultati pokazuju da s brojem maloljetne djece u kućanstvima raste i PPS, pa PPS osoba koje nemaju djece iznosi $29,5 \%$, dok je PPS osoba s troje ili više djece $42,1 \%$. Također, puno veći udio osoba s troje ili više djece ima vrlo visok PPS, njih $12,6 \%$, za razliku od osoba bez djece kojih tek $1,4 \%$ ima vrlo visok PPS. PPS se razlikuje i prema visini tržišnog dohotka ostalih članova kućanstva. Osobe čiji članovi kućanstva ostvaruju tržišni dohodak manji od 500 kn imaju najveći PPS, koji iznosi 46,7\%, a $14,8 \%$ takvih osoba ima vrlo visok PPS.

Nadalje, da bi se otkrilo kako različiti elementi sustava poreza i socijalnih naknada doprinose ukupnom PPS-u, u Tablici 3. dana je dekompozicija PPS-a prema različitim podskupinama nezaposlenih i neaktivnih osoba. Stupci (1) do (5) označavaju doprinos određenih elemenata ukupnom PPS-u, a njihov zbroj je prikazan u stupcu (6) koji označava ukupni PPS. Prvo, doprinosi iz plaće (stupac 1) imaju jednak doprinos ukupnom PPS-u od 20 postotnih bodova za sve podskupine, a to je ujedno i najznačajniji čimbenik ukupnog PPS-a. Prosječni doprinos poreza na dohodak i prireza (stupac 2) ukupnom PPS-u za sve neaktivne i nezaposlene osobe iznosi 5,1 postotnih bodova, a taj element najveći doprinos ima za podskupinu s višim/visokim obrazovanjem ( 9,0 postotnih bodova) i osobe koje žive u urbanim područjima $(6,7$ postotnih bodova). Spomenute podskupine mogu ostvariti više plaće od ostalih pa progresivnost poreza na dohodak rezultira povećanim doprinosom poreza na dohodak ukupnom PPS-u. S druge strane, porez na dohodak i prirez imaju najmanji doprinos ukupnom PPS-u za podskupine osoba s troje ili više djece (1,3 postotnih bodova); osobni odbitak raste s brojem uzdržavanih osoba pa osobe s više djece plaćaju manje iznose poreza.

Tablica 3.

Dekompozicija PPS-a prema različitim podskupinama u Hrvatskoj

\begin{tabular}{|c|c|c|c|c|c|c|}
\hline & DIP & PND & DPZD & SOCN & $\mathrm{NZN}$ & UK PPS \\
\hline & (1) & (2) & (3) & (4) & (5) & (6) \\
\hline Ukupno & 20,0 & 5,1 & 2,0 & 3,5 & 0,7 & 31,3 \\
\hline \multicolumn{7}{|l|}{ Dob } \\
\hline $18-30$ & 20,0 & 5,2 & 2,1 & 2,5 & 0,1 & 29,9 \\
\hline $31-50$ & 20,0 & 4,4 & 3,1 & 4,3 & 0,4 & 32,2 \\
\hline $51-65$ & 20,0 & 6,0 & 0,5 & 3,0 & 1,5 & 31,0 \\
\hline \multicolumn{7}{|l|}{ Spol } \\
\hline Muško & 20,0 & 4,5 & 1,0 & 4,0 & 0,6 & 30,1 \\
\hline Žensko & 20,0 & 5,5 & 2,8 & 3,1 & 0,7 & 32,1 \\
\hline \multicolumn{7}{|l|}{ Obrazovanje } \\
\hline Osnovno & 20,0 & 4,8 & 1,9 & 18,8 & 1,3 & 46,8 \\
\hline Srednje & 20,0 & 4,6 & 2,0 & 3,5 & 0,7 & 30,8 \\
\hline Više/visoko & 20,0 & 9,0 & 1,7 & 0,9 & 0,3 & 31,9 \\
\hline \multicolumn{7}{|l|}{ Gustoća naseljenosti } \\
\hline Ruralna područja & 20,0 & 4,3 & 2,4 & 4,1 & 0,6 & 31,4 \\
\hline Srednje naseljena područja & 20,0 & 5,1 & 1,8 & 3,2 & 0,9 & 31,0 \\
\hline Urbana područja & 20,0 & 6,7 & 1,5 & 2,8 & 0,6 & 31,6 \\
\hline \multicolumn{7}{|l|}{ Broj djece } \\
\hline Nema djece & 20,0 & 5,8 & 0,1 & 2,9 & 0,7 & 29,5 \\
\hline Jedno dijete & 20,0 & 5,4 & 2,8 & 2,8 & 0,3 & 31,3 \\
\hline Dva djeteta & 20,0 & 2,9 & 5,1 & 2,8 & 0,9 & 31,7 \\
\hline Troje ili više djece & 20,0 & 1,3 & 9,7 & 9,9 & 1,2 & 42,1 \\
\hline
\end{tabular}

Kratice: DIP - doprinos iz plaće; PND - porez na dohodak i prirez; DPZD - doplatak za djecu; SOCN - ZMN i naknada za troškove stanovanja; NZN - naknada za nezaposlene; UK PPS - ukupni PPS.

Izvor: Autorovi izračuni koristeći mikrosimulacijski model EUROMOD i podatke EU-SILC 2018. 
Kako je i za očekivati, doplatak za djecu (stupac 3) ima najveći doprinos od 9,7 postotnih bodova ukupnom PPS-u za podskupinu osoba s troje ili više djece, dok prosječni doprinos tog elementa za sve neaktivne i nezaposlene osobe iznosi 2,0 postotnih bodova. Primatelji doplatka za djecu dobivaju određeni iznos doplatka za svako dijete, pa ukupan iznos doplatka raste s brojem djece, a dodatno primatelji doplatka za djecu imaju pravo i na pronatalitetni dodatak koji se dodjeljuje za treće i četvrto dijete. Nadalje, ZMN i naknada za troškove stanovanja (stupac 4) najveći doprinos ukupnom PPS-u od 18,8 i 9,9 postotnih bodova imaju redom za podskupine osoba s osnovnim stupnjem obrazovanja i osobe s troje ili više djece, a prosječni doprinos tih elemenata za sve neaktivne i nezaposlene je 3,5 postotnih bodova. Razlog tome je što osobe niskog stupnja obrazovanja teže pronalaze posao pa su sklonije primanju naknada čija je svrha zadovoljavanje osnovnih životnih potreba. Također obitelji s više djece imaju veći broj uzdržavanih članova, pa se $s$ brojem djece povećava i potencijalni iznos ZMN-a i naknade za troškove stanovanja. Prosječni doprinos naknade za nezaposlene (stupac 5) je 0,7 postotna boda, a najveći doprinos te naknade ima podskupina osoba od 51 do 65 godina (1,5 postotnih bodova). Duljina razdoblja u kojem se prima naknada za nezaposlene ovisi o godinama provedenim na prethodnom poslu pa su starije osobe kandidati koji su na godišnjoj razini skloniji primanju većih iznosa te naknade nego mlađe osobe.

\section{Isplativost rada u Sloveniji}

U ovom dijelu analizira se distribucija PPS-a u Sloveniji prema različitim podskupinama neaktivnih i nezaposlenih osoba, a potom je napravljena dekompozicija PPS-a prema elementima sustava poreza i socijalnih naknada. U obzir su uzeti sljedeći tipovi naknada i poreza: naknada za nezaposlene, socijalna pomoć, doplatak za djecu, subvencija najamnine, porez na dohodak $\mathrm{i}$ doprinosi iz plaće. Opis sustava poreza i socijalnih naknada u Sloveniji može se vidjeti u izvještaju EUROMOD Country Report, Slovenia 2017-2020 (Kump i sur., 2020.).

Analiziraju se nezaposlene i neaktivne osobe, koje čine 7\% radno sposobne populacije (žena u dobi 18-60 i muškaraca u dobi 18-65). Analiza počinje Tablicom 4. koja pokazuje da prosječni PPS za neaktivne i nezaposlene osobe u Sloveniji iznosi 42,6\%, pri čemu $23,6 \%$ promatranih osoba ima PPS između 50 i 70\%, dok 1,6\% osoba ima PPS iznad $70 \%$. Tako u Sloveniji četvrtina neaktivnih i nezaposlenih osoba ima visok ili vrlo visok PPS.

Što se tiče podjele prema dobi, osobe mlađe dobi (18-30 godina) imaju najmanji PPS $(40,0 \%)$, najviši PPS $(43,5 \%)$ imaju osobe starije dobi (51-65 godina), dok je PPS osoba srednje dobi (31-50 godina) gotovo jednak prosjeku za sve neaktivne i nezaposlene osobe i iznosi 42,7\%. Međutim, najveći udio osoba srednje dobi, njih 2,5\% od 39 tisuća, ima vrlo visok PPS. Nadalje, muškarci (njih 35 tisuća) i žene (njih 49 tisuća) imaju približno jednak PPS, PPS muškaraca iznosi 42,9\%, a kod žena iznosi $42,4 \%$. Nešto veći udio žena ima vrlo visok PPS, njih 2,0\%, dok je taj postotak kod muškaraca nešto niži i iznosi $1,1 \%$.

Za razliku od Hrvatske, u uzorku za Sloveniju nema punoljetnih osoba koje imaju samo osnovni stupanj obrazovanja pa se u smislu analize PPS-a promatraju samo osobe sa srednjim i višim/visokim stupnjem obrazovanja. Obje podskupine imaju približno jednak PPS, PPS za osobe sa srednjim stupnjem obrazovanja je 42,9\%, dok osobe s višim/visokim stupnjem obrazovanja imaju za 1,4 postotnih bodova niži PPS. 
Tablica 4.

Distribucija PPS-a prema određenim demografskim i socioekonomskim karakteristikama u Sloveniji, u \%

\begin{tabular}{|c|c|c|c|c|c|c|}
\hline & \multirow{2}{*}{$\begin{array}{l}\text { Broj neaktivnih } \\
\text { i nezaposlenih } \\
\text { osoba (u tis.) }\end{array}$} & \multirow{2}{*}{$\begin{array}{c}\text { Prosječni PPS } \\
\text { (standardna } \\
\text { pogreška) }\end{array}$} & \multicolumn{4}{|c|}{$\begin{array}{c}\text { Distribucija populacije prema razredima } \\
\text { PPS-a }\end{array}$} \\
\hline & & & $<30 \%$ & {$[30 \%, 50 \%>$} & {$[50 \%, 70 \%>$} & $\geq 70 \%$ \\
\hline Ukupno & 84 & $42,6(0,0032)$ & 4,9 & 70,0 & 23,6 & 1,6 \\
\hline \multicolumn{7}{|l|}{ Dob } \\
\hline $18-30$ & 12 & $40,0(0,0079)$ & 8,4 & 73,3 & 17,1 & 1,2 \\
\hline $31-50$ & 39 & $42,7(0,0048)$ & 2,8 & 73,9 & 20,8 & 2,5 \\
\hline $51-65$ & 33 & $43,5(0,0052)$ & 6,1 & 64,1 & 29,2 & 0,7 \\
\hline \multicolumn{7}{|l|}{ Spol } \\
\hline Muško & 35 & $42,9(0,0052)$ & 4,6 & 66,4 & 28,0 & 1,1 \\
\hline Žensko & 49 & $42,4(0,0042)$ & 5,0 & 72,5 & 20,5 & 2,0 \\
\hline \multicolumn{7}{|l|}{ Obrazovanje } \\
\hline Srednje & 69 & $42,9(0,0037)$ & 5,8 & 67,9 & 24,4 & 2,0 \\
\hline Više/visoko & 15 & $41,5(0,0059)$ & 0,3 & 79,8 & 19,9 & 0,0 \\
\hline \multicolumn{7}{|l|}{ Broj djece } \\
\hline Nema djece & 56 & $41,7(0,0040)$ & 6,3 & 67,4 & 25,7 & 0,6 \\
\hline Jedno dijete & 14 & $43,1(0,0077)$ & 2,6 & 74,7 & 20,4 & 2,4 \\
\hline Dva djeteta & 9 & $44,8(0,0091)$ & 1,3 & 80,4 & 16,1 & 2,3 \\
\hline Troje ili više djece & 5 & $46,9(0,0141)$ & 1,4 & 66,9 & 21,7 & 10,1 \\
\hline \multicolumn{7}{|c|}{ Tržišni dohodak ostalih članova kućanstva (u EUR) } \\
\hline 0 do 50 & 15 & $52,7(0,0083)$ & 0,0 & 33,3 & 63,1 & 3,6 \\
\hline 50 do 500 & 10 & $51,3(0,0113)$ & 2,2 & 43,9 & 47,8 & 6,2 \\
\hline 500 do 1000 & 13 & $41,1(0,0079)$ & 5,0 & 77,3 & 16,8 & 0,9 \\
\hline 1000 do 2000 & 24 & $39,1(0,0046)$ & 6,6 & 83,0 & 10,1 & 0,3 \\
\hline više od 2000 & 22 & $36,4(0,0031)$ & 7,4 & 88,6 & 4,0 & 0,0 \\
\hline
\end{tabular}

Izvor: Autorovi izračuni koristeći mikrosimulacijski model EUROMOD i podatke EU-SILC 2018.

Očekivano, PPS raste s brojem maloljetne djece u kućanstvima. PPS osoba koje nemaju djece iznosi $41,7 \%$, dok PPS osoba s troje ili više djece iznosi 46,9\%. Također, puno veći udio osoba s troje ili više djece, njih $10,1 \%$, ima vrlo visok PPS, za razliku od osoba bez djece kojih tek $0,6 \%$ ima vrlo visok PPS. Nadalje, PPS se razlikuje ovisno o visini tržišnog dohotka ostalih članova kućanstva. Osobe čiji članovi kućanstva ostvaruju tržišni dohodak manji od 50 eura imaju najveći PPS koji iznosi 52,7\%, a 3,6\% takvih osoba ima vrlo visok PPS. S druge strane, najmanji PPS u iznosu od 36,4\% imaju osobe čiji članovi kućanstva ostvaruju tržišni dohodak veći od 2 tisuće eura, a takve osobe nemaju vrlo visok PPS.

Nadalje, Tablica 5. prikazuje dekompoziciju PPS-a prema različitim podskupinama nezaposlenih i neaktivnih osoba. U stupcima (1) do (5) prikazuje se doprinos određenih elemenata ukupnom PPS-u, a njihov zbroj nalazi se u stupcu (6) koji označava ukupni PPS. Doprinosi iz plaće (stupac 1) imaju jednak doprinos PPS-u od 22,1 postotnih bodova za sve podskupine, a to je ujedno i najznačajniji čimbenik ukupnog PPS-a. Na razini svih neaktivnih i nezaposlenih oso- 
ba doprinos poreza na dohodak (stupac 2) iznosi 9,7 postotnih bodova, a najveći doprinos tog elementa ukupnom PPS-u prisutan je za osobe s višim/visokim obrazovanjem (11,1 postotnih bodova), osobe starije generacije (10,6 postotnih bodova) i osobe bez djece (10,3 postotnih bodova). Osobe $\mathrm{s}$ višim stupnjem obrazovanja i osobe starije dobi uglavnom imaju i veće plaće od ostalih podskupina pa uplaćuju i veće iznose poreza na dohodak. Što se tiče osoba bez djece, poznato je da vrijednost osobnog odbitka raste $\mathrm{s}$ brojem djece, pa osobe bez djece plaćaju veće iznose poreza na dohodak nego osobe s djecom. neaktivnih i nezaposlenih osoba iznosi 1,4 postotnih bodova. Razlog tome je što doplatak za djecu raste s brojem djece, a primatelji doplatka dodatno imaju pravo i na dodatak za treće ili četvrto dijete. Što se tiče socijalne pomoći i subvencije najamnine (stupac 4), najveći doprinos tih naknada ukupnom PPS-u imaju osobe s djecom. Za osobe s dvoje djece doprinos iznosi 8,7, za osobe s troje ili više djece iznosi 11,4 postotnih bodova, dok prosječni doprinos tog elementa iznosi 6,6 postotnih bodova. Nadalje, kao i u Hrvatskoj, duljina razdoblja primanja naknade za nezaposlene ovisi o vremenskom razdoblju provedenom na prethodnom poslu, pa tako

Tablica 5.

Dekompozicija PPS-a prema različitim podskupinama u Sloveniji

\begin{tabular}{|c|c|c|c|c|c|c|}
\hline & DIP & PND & DPZD & SOCN & $\mathrm{NZN}$ & UK PPS \\
\hline & (1) & $(2)$ & $(3)$ & (4) & (5) & $(6)$ \\
\hline Ukupno & 22,1 & 9,7 & 1,4 & 6,6 & 2,8 & 42,6 \\
\hline \multicolumn{7}{|l|}{ Dob } \\
\hline $18-30$ & 22,1 & 9,2 & 1,3 & 6,2 & 1,2 & 40,0 \\
\hline $31-50$ & 22,1 & 9,2 & 2,3 & 7,7 & 1,4 & 42,7 \\
\hline $51-65$ & 22,1 & 10,6 & 0,3 & 5,6 & 4,9 & 43,5 \\
\hline \multicolumn{7}{|l|}{ Spol } \\
\hline Muško & 22,1 & 9,9 & 0,6 & 7,1 & 3,2 & 42,9 \\
\hline Žensko & 22,1 & 9,6 & 2,0 & 6,3 & 2,4 & 42,4 \\
\hline \multicolumn{7}{|l|}{ Obrazovanje } \\
\hline Srednje & 22,1 & 9,6 & 1,2 & 7,4 & 2,6 & 42,9 \\
\hline Više/visoko & 22,1 & 11,1 & 1,7 & 3,2 & 3,4 & 41,5 \\
\hline \multicolumn{7}{|l|}{ Broj djece } \\
\hline Nema djece & 22,1 & 10,3 & 0,0 & 5,7 & 3,6 & 41,7 \\
\hline Jedno dijete & 22,1 & 9,6 & 2,6 & 7,4 & 1,4 & 43,1 \\
\hline Dva djeteta & 22,1 & 8,8 & 5,0 & 8,7 & 0,2 & 44,8 \\
\hline Troje ili više djece & 22,1 & 6,2 & 6,4 & 11,4 & 0,8 & 46,9 \\
\hline
\end{tabular}

Kratice: DIP - doprinos iz plaće; PND - porez na dohodak; DPZD - doplatak za djecu; SOCN - socijalna pomoć i subvencija najamnine; NZN - naknada za nezaposlene; UK PPS - ukupni PPS.

Izvor: Autorovi izračuni koristeći mikrosimulacijski model EUROMOD i podatke EU-SILC 2018.

Doplatak za djecu (stupac 3) ima najveći doprinos ukupnom PPS-u od 6,4 postotnih bodova za podskupinu osoba s troje ili više djece, a doprinos tog elementa na razini svih najveći doprinos te naknade ukupnom PPS-u od 4,9 postotnih bodova ima podskupina osoba od 51 do 65 godina, a prosječni doprinos iznosi 2,8 postotnih bodova. 


\section{Komparativna analiza isplativosti rada za Hrvatsku i Sloveniju}

Komparativna analiza PPS-a pokazuje da Slovenija ima veći prosječni PPS nego Hrvatska (Tablica 6.). Preciznije, analiza otkriva da je prosječni PPS u Sloveniji za 11,3 postotnih bodova veći nego u Hrvatskoj; prosječni PPS u Sloveniji iznosi 42,6\%, dok u Hrvatskoj iznosi 31,3\%. Nadalje, pokazalo se da Slovenija ima veći udio neaktivnih i nezaposlenih osoba s visokim i vrlo visokim PPS-om nego Hrvatska; 25,2\% neaktivnih i nezaposlenih osoba ima visok i vrlo visok PPS u Sloveniji, dok u Hrvatskoj 8,7\% takvih osoba ima visok i vrlo visok PPS.
Komparativna analiza prema odabranim podskupinama otkriva da je za svaku promatranu podskupinu neaktivnih i nezaposlenih osoba prosječni PPS veći u Sloveniji nego u Hrvatskoj. U Hrvatskoj, najveći udio osoba s visokim i vrlo visokim PPS-om od oko $43 \%$ ima podskupina osoba s osnovnim stupnjem obrazovanja, dok prema EU-SILC podatcima u Sloveniji niti jedna odrasla osoba nema niži stupanj obrazovanja od srednjeg. Međutim, 26,4\% osoba sa srednjim stupnjem obrazovanja u Sloveniji ima visok i vrlo visok PPS, a u Hrvatskoj je taj udio manji za 18 postotnih bodova. S druge strane, u Sloveniji najveći udio osoba

Tablica 6.

Komparativna analiza distribucije PPS-a između Hrvatske i Slovenije (u \%)

\begin{tabular}{|c|c|c|c|c|c|c|}
\hline & \multicolumn{3}{|c|}{ Hrvatska } & \multicolumn{3}{|c|}{ Slovenija } \\
\hline & \multirow{2}{*}{$\begin{array}{l}\text { Prosječni } \\
\text { PPS }\end{array}$} & \multicolumn{2}{|c|}{$\begin{array}{c}\text { Distribucija populacije prema } \\
\text { razredima PPS-a }\end{array}$} & \multirow{2}{*}{$\begin{array}{l}\text { Prosječni } \\
\text { PPS }\end{array}$} & \multicolumn{2}{|c|}{$\begin{array}{l}\text { Distribucija populacije } \\
\text { prema razredima PPS-a }\end{array}$} \\
\hline & & {$[50 \%, 70 \%>$} & $\geq 70 \%$ & & {$[50 \%, 70 \%>$} & $\geq 70 \%$ \\
\hline Ukupno & 31,3 & 5,9 & 2,8 & 42,6 & 23,6 & 1,6 \\
\hline \multicolumn{7}{|l|}{ Dob } \\
\hline $18-30$ & 29,9 & 7,9 & 0,9 & 40,0 & 17,1 & 1,2 \\
\hline $31-50$ & 32,2 & 5,3 & 4,8 & 42,7 & 20,8 & 2,5 \\
\hline $51-65$ & 31,0 & 5,5 & 1,3 & 43,5 & 29,2 & 0,7 \\
\hline \multicolumn{7}{|l|}{ Spol } \\
\hline Muško & 30,1 & 4,5 & 1,6 & 42,9 & 28,0 & 1,1 \\
\hline Žensko & 32,1 & 6,7 & 3,6 & 42,4 & 20,5 & 2,0 \\
\hline \multicolumn{7}{|l|}{ Obrazovanje } \\
\hline Osnovno & 46,8 & 30,5 & 12,2 & - & - & - \\
\hline Srednje & 30,8 & 5,5 & 2,9 & 42,9 & 24,4 & 2,0 \\
\hline Više/visoko & 31,9 & 2,2 & 0,2 & 41,5 & 19,9 & 0,0 \\
\hline \multicolumn{7}{|l|}{ Broj djece } \\
\hline Nema djece & 29,5 & 3,8 & 1,4 & 41,7 & 25,7 & 0,6 \\
\hline Jedno dijete & 31,3 & 4,6 & 2,4 & 43,1 & 20,4 & 2,4 \\
\hline Dva djeteta & 31,7 & 8,1 & 2,9 & 44,8 & 16,1 & 2,3 \\
\hline Troje ili više djece & 42,1 & 18,1 & 12,6 & 46,9 & 21,7 & 10,1 \\
\hline
\end{tabular}

Izvor: Autorovi izračuni koristeći mikrosimulacijski model EUROMOD i podatke EU-SILC 2018. 
s visokim i vrlo visokim PPS-om od 31,8\% ima podskupina osoba s troje ili više djece, a u Hrvatskoj je taj udio manji za 1 postotni bod. Što se tiče podjele prema spolu, pokazalo se da u Sloveniji veći udio muškaraca i žena ima visok i vrlo visok PPS nego u Hrvatskoj. Točnije, 22,5\% žena i $29,1 \%$ muškaraca u Sloveniji ima visok i vrlo visok PPS, a u Hrvatskoj je taj udio manji za 12,2 postotnih bodova kod žena i $23,0 \%$ postotnih bodova kod muškaraca. Nadalje, žene u Sloveniji imaju niži prosječni PPS od muškaraca, dok je u Hrvatskoj situacija obrnuta pa žene imaju viši prosječni PPS nego muškarci.

\section{Usporedba rezultata s ranijim istraživanjima}

Budući da se prema izvoru podataka ovo istraživanje PPS-a u Hrvatskoj i Sloveniji razlikuje od prethodnih studija koja su napravljena na hipotetskim podatcima, u ovom poglavlju uspoređuju se rezultati ovog istraživanja s prethodnim istraživanjima na hipotetskim podatcima. Od dosadašnjih analiza na hipotetskim podatcima, uzimaju se novija istraživanja koja su provedena za 2016. (Laporšek i sur. 2019.) i 2018. (Bezeredi, 2019.) godinu. Najčešći tip kućanstava u populaciji je samac, pa se taj tip kućanstva uzima kao »predstavnik« hipotetskih analiza.

Tablica 7. pokazuje kako postoje bitne razlike između rezultata dobivenih na temelju anketnih i hipotetskih podataka. Iz stupaca (2) i (4) vidi se da je u Hrvatskoj na temelju hipotetskih analiza dobiveno da PPS samaca koji se zapošljavaju uz bruto plaće od $50 \%$ i $100 \%$ prosječne bruto plaće redom iznosi $49 \%$ i $44 \%$. S druge strane, ovo istraživanje na temelju anketnih podataka sugerira da je prosječni PPS u Hrvatskoj dosta manji te da iznosi $31 \%$. Isto se pokazalo i za Sloveniju, PPS na temelju hipotetskih analiza iznosi oko $60 \%$, dok ovo istraživanje pokazuje da je prosječni PPS oko $43 \%$.

Tablica 7.

Usporedba PPS-a s ranijim istraživanjima (u \%)

\begin{tabular}{|c|c|c|c|c|c|c|c|}
\hline \multirow{4}{*}{ Godina } & \multicolumn{5}{|c|}{ Prethodna istraživanja } & \multirow{3}{*}{\multicolumn{2}{|c|}{$\begin{array}{c}\text { Ovo istraživanje } \\
\text { Prosječni PPS na } \\
\text { temelju EU-SILC } \\
\text { podataka }\end{array}$}} \\
\hline & \multirow{3}{*}{ Istraživanje } & \multicolumn{4}{|c|}{$\begin{array}{l}\text { PPS hipotetskog samca koji radi } \\
\text { uz bruto plaću od: }\end{array}$} & & \\
\hline & & \multicolumn{2}{|c|}{$50 \%$ PBP-a } & \multicolumn{2}{|c|}{$100 \%$ PBP-a } & & \\
\hline & & $\mathrm{HR}$ & SLO & $\mathrm{HR}$ & SLO & $\mathrm{HR}$ & SLO \\
\hline & (1) & (2) & (3) & (4) & (5) & (6) & (7) \\
\hline 2016. & $\begin{array}{l}\text { Laporšek i sur. } \\
(2019)\end{array}$ & - & 62 & - & 57 & - & - \\
\hline 2017. & - & - & - & - & - & 31 & 43 \\
\hline 2018. & $\begin{array}{l}\text { Bezeredi i sur. } \\
\text { (2019.) }\end{array}$ & 49 & 60 & 44 & - & - & - \\
\hline
\end{tabular}

Izvor: Podaci u stupcima (2) do (5) preuzeti su iz ranijih istraživanja navedenih u stupcu (1), a podaci u stupcima (6) i (7) odnose se na ovo istraživanje i preuzeti su iz tablice 6. 
Iz navedenog se vidi kako rezultati hipotetskih analiza mogu navesti na krive zaključke o visini PPS-a u zemlji. Hipotetske analize temelje se na nizu pretpostavki i na temelju njih je teško donositi bilo kakve odluke, budući da je gotovo nemoguće u analizu uključiti sve tipove kućanstava. Stoga bi prije donošenja reformi svakako bilo korisno napraviti analize na temelju stvarnih podataka, što može biti korisna spoznaja i za kreatore socijalne ili porezne politike.

\section{ZAKLJUČAK}

Izdašni sustavi socijalnih naknada mogu smanjiti poticaje za rad neaktivnih i nezaposlenih osoba. Naime, ako neaktivne i nezaposlene osobe svojim zapošljavanjem gube pravo na izdašne naknade iz socijalnog sustava, to može smanjiti poticaje takvih osoba za pronalaskom i prihvaćanjem novog zaposlenja.

Glavni cilj rada bio je analizirati utjecaj poreza i socijalnih naknada na isplativost rada u Hrvatskoj i Sloveniji. Promatrale su se neaktivne i nezaposlene osobe i njihov hipotetski prelazak u zaposlenost, a kao glavni pokazatelj isplativosti rada izračunavala se participacijska porezna stopa (PPS) koja mjeri koliki će dio bruto plaće ostvarene na novom poslu biti izgubljen iz proračuna kućanstava zbog povećanja iznosa plaćenih poreza i smanjenja iznosa primljenih socijalnih naknada. Analiza je, po prvi put u obje zemlje, provedena koristeći anketne podatke, čime se dobila realna slika stanja na području isplativosti rada. Za procjenu PPS-a koristio se EUROMOD, mikrosimulacijski model poreza i socijalnih naknada za zemlje EU-a koji se zasniva na pravilima sustava poreza i socijalnih naknada koja su vrijedila za 2017. Model koristi EU-SILC podatke za 2018., pri čemu se dohodovne varijable odnose na stanje iz 2017., što znači da se dobiveni rezultati istraživanja odnose na 2017. godinu.

Rezultati su pokazali da je prosječni PPS u Hrvatskoj umjerene veličine u iznosu od $31,3 \%$, te da značajan udio neaktivnih i nezaposlenih osoba (njih 8,7\%) ima visok i vrlo visok PPS (veći od 50\%). S druge strane, prosječni PPS u Sloveniji iznosi 42,6\%, što je za 11,3 postotnih bodova više nego u Hrvatskoj. Nadalje, četvrtina neaktivnih i nezaposlenih osoba u Sloveniji ima visok i vrlo visok PPS.

Za obje zemlje pokazalo se kako najviši prosječni PPS imaju: (i) osobe čiji supružnici i ostali članovi kućanstva mogu ostvariti samo niske iznose tržišnog dohotka (41 tisuća takvih osoba u Hrvatskoj ima prosječni PPS od 46,7\%, a u Sloveniji ih 15 tisuća ima prosječni PPS od 52,7\%); (ii) osobe s troje ili više djece (u Hrvatskoj 33 tisuće takvih osoba ima prosječni PPS od $42,1 \%$, a u Sloveniji ih 5 tisuća ima prosječni PPS od 46,9\%). Dodatno, za Hrvatsku se utvrdilo da su i osobe s osnovnim stupnjem obrazovanja među onima s najvišim prosječnim PPS-om (njih 10 tisuća ima prosječni PPS 46,8\%), dok prema EU-SILC anketi u Sloveniji nema odraslih osoba s tako niskim stupnjem obrazovanja.

Dekompozicija PPS-a prema elementima sustava poreza i socijalnih naknada pokazuje kako su doprinosi na plaću najznačajniji čimbenici ukupnog PPS-a, a njihov doprinos je u obje zemlje konstantan za sve podskupine neaktivnih i nezaposlenih osoba. Nadalje, za podskupine osoba s najvišim PPS-om (osobe s više djece i osobe s nižim stupnjem obrazovanja) potvrdilo se da su ZMN i naknada za troškove stanovanja u Hrvatskoj te socijalna pomoć i subvencija najamnine u Sloveniji elementi koji utječu da te podskupine imaju PPS veći od prosjeka za sve neaktivne i nezaposlene osobe. Kod osoba s djecom, doplatak za djecu isto postaje važan čimbenik koji takve osobe čini osobama s PPS-om većim od prosjeka. S druge strane, kod prethodno spomenutih podskupina s višim PPS-om, doprinos poreza na dohodak ukupnom PPS-u je čak i niži od prosjeka za sve neaktivne i nezaposlene osobe pa se za taj element ne može zaključiti da povećava PPS »najugroženijih« skupina. 
Dosadašnja istraživanja PPS-a na hipotetskim podatcima u Hrvatskoj (Bejaković i sur., 2012.; Bezeredi, 2019.) i Sloveniji (Dolenc i Vodopivec, 2005.; Laporšek, Vodopivec i Vodopivec, 2019.) ukazala su na problem da određene podskupine kućanstva imaju vrlo niske financijske poticaje za ulazak neaktivnih i nezaposlenih osoba $\mathrm{u}$ zaposlenost, no nisu otkrila koliko ima takvih kućanstava. Ovo istraživanje potvrdilo je da postoje podskupine neaktivnih i nezaposlenih osoba s PPS-om većim od 50\% i dodatno pokazalo da postoji značajan broj takvih podskupina. Kao glavni uzročnici niske isplativosti rada pokazali su se viši iznosi socijalnih transfera. Stoga bi prilikom budućih reformi socijalnog sustava, uz glavnu svrhu socijalnih transfera koja je očuvanje minimalnog životnog standarda, trebalo dodatno osigurati da viši iznosi naknada ne djeluju previše negativno na isplativost rada. Svakako bi trebalo slijediti i preporuke istraživanja Laporšek, Vodopivec i Vodopivec (2019.) i razmotriti uvođenje naknade koju bi primale zaposlene osobe s niskom plaćom (engl. in-work benefits), čime bi se poboljšala isplativost rada, odnosno smanjio negativan utjecaj socijalnih naknada na isplativost rada. Takve politike bi kroz poticanje povećanja zaposlenosti »najranjivijih « skupina dodatno doprinijele i ravnomjernijoj raspodjeli dohotka, kao i smanjenju siromaštva zaposlenih osoba. ${ }^{10}$ Međutim, prije uvođenja takvih naknada potrebne su detaljnije analize, što može biti preporuka za daljnja istraživanja.

Ograničenja istraživanja proizlaze iz ograničenja mikrosimulacijskog modela EUROMOD-a i anketnih (EU-SILC) podataka. Ograničenja u podacima posljedično smanjuju točnost procjena mikrosimulacijskih modela koji pak koriste te podatke.
Neka od ograničenja podataka su nedostatak informacija o imovini i agregiranje varijabli dohotka na godišnjoj razini čime se onemogućuje precizno definiranje dohodovnih cenzusa koji se koriste u simulaciji programa socijalne pomoći. U svrhu anonimizacije podataka u EU-SILC anketi je više vrsta socijalnih naknada agregirano u jednu varijablu što također smanjuje točnost procjena modela. Nadalje, zbog nedostatka preciznih podataka o svim vrstama socijalnih naknada i poreznih davanja, u EUROMOD se ugrađuju samo najznačajnije politike iz sustava poreza i socijalnih naknada u pojedinoj državi. Porezna evazija također nije modelirana u EUROMOD-u zbog nedostatka podataka, a pretpostavlja se da se naknade ubiru u cijelosti. Međutim, uz sva navedena ograničenja, ovo istraživanje daje reprezentativnu sliku stanja u obje analizirane zemlje.

\section{Zahvala}

Ovaj rad dijelom je sufinancirala $\mathrm{Hr}$ vatska zaklada za znanost projektom IP2019-04-9924 (Utjecaj poreza i socijalnih naknada na raspodjelu dohotka i ekonomsku efikasnost). Rad je nastao ažuriranjem, prilagodbom i dopunom dijela doktorske disertacije Slavka Bezeredija pod naslovom »Analiza utjecaja sustava poreza i socijalnih naknada na isplativost rada u Republici Hrvatskoj upotrebom mikrosimulacijskih modela« (Ekonomski fakultet Sveučilišta u Zagrebu). Rezultati se temelje na EUROMOD-u (verziji I2.0+) koji, u suradnji s nacionalnim timovima članica EU-a, zajednički održava, razvija i njime upravlja Institut za društvena i ekonomska istraživanja (ISER) na Sveučilištu u Essexu i Zajednički istraživački centar (JRC) Europske komisije. Proces njegovog proširenja i ažu-

\footnotetext{
${ }^{10}$ Navedeno se pokazalo točno u istraživanjima za Veliku Britaniju (Browne, Hood i Joyce, 2016.) i Francusku (Canova, Piccoli i Spadaro, 2015.) u kojima su naknade za zaposlene osobe s niskom plaćom povećale dohotke kućanstava i smanjile stopu siromaštva.
} 
riranja financijski podupire EU Program za zapošljavanje i socijalne inovacije »EaSI« (2014. - 2020.). Zahvalan sam svim ljudima koji su doprinijeli razvoju EUROMOD-a. Zahvalan sam Eurostat-u na pristupu mikropodatcima iz EU Ankete o dohotku i životnim uvjetima (EU-SILC 2018) za Hrvatsku i Sloveniju.

\section{LITERATURA}

Adam, S., \& Browne, J. (2010). Redistribution, work incentives and thirty years of UK tax and benefit reform. Institute for Fiscal Studies Working Paper 10/24. Available at https://www.ifs.org. uk/wps/wp1024.pdf

Bargain, O., \& Orsini, K. (2006). In-work policies in Europe: killing two birds with one stone?. Labour Economics, 13(6), 667-697. https://doi. org/10.1016/j.labeco.2005.10.007

Bargain, O., Caliendo, M., Haan, P., \& Orsini, K. (2010). "Making work pay" in a rationed labor market. Journal of Population Economics, 23(1), 323-351. https://doi.org/10.1007/s00148008-0220-9

Bejaković P., Urban I., Bezeredi S., \& Matejina A. (2012). Isplati li se raditi u Hrvatskoj? Revija za socijalnu politiku, 19(1), 83-92. https://doi. org/10.3935/rsp.v19i1.1054

Bezeredi, S. (2019). Utjecaj reformi poreza i socijalnih naknada na isplativost rada u Hrvatskoj od 2013. do 2018. Ekonomska misao i praksa, (2), 167-192. https://hrcak.srce.hr/230543

Bezeredi, S., \& Urban, I. (2016). Predicting gross wages of non-employed persons in Croatia. $\mathrm{Fi}$ nancial Theory and Practice, 40(1), 1-61. https:// doi.org/10.3326/fintp.40.1.1

Bezeredi, S., Ledić, M., Rubil, I., \& Urban, I. (2019). Making work pay in Croatia: An ex-ante evaluation of two in-work benefits using miCROmod. International Journal of Microsimulation, 12(3), 28-61. https://doi.org/10.34196/ijm.00206

Blundell, R., Bozio, A., \& Laroque, G. (2013). Extensive and intensive margins of labour supply: Work and working hours in the US, the UK and France. Fiscal Studies, 34(1), 1-29. https://doi. org/10.1111/j.1475-5890.2013.00175.x

Browne, J., Hood, A., \& Joyce, R. (2016). The (changing) effects of universal credit. In C. Emmerson, P. Johnson \& R. Joyce (Eds.), The IFS Green Budget Report 2016 (pp. 232-259). London: IFS. Available at https://www.ifs.org.uk/uploads/gb/ gb2016/gb2016.pdf

Canova, L., Piccoli, L., \& Spadaro, A. (2015). An ex ante evaluation of the Revenu de Solidarité
Active by micro-macro simulation techniques. IZA Journal of European Labor Studies, 4(17). https://doi.org/10.1186/s40174-015-0040-3

Carone, G., Immervoll, H., Paturot, D., \& Salomäki, A. (2004). Indicators of unemployment and low-wage traps: Marginal effective tax rates on employment incomes. OECD Social, Employment and Migration Working Papers, No. 18. https://doi.org/10.1787/137550327778

Carone, G., Stovicek, K., Pierini, F., \& Sail, E. (2009). Recent reforms of the tax and benefit systems in the framework of flexicurity. European Communities. Occasional Papers, 43. Brussels: European Commission. Available at https://ec.europa. eu/economy_finance/publications/pages/publication14173_en.pdf

Dolenc, P., \& Vodopivec, M. (2005). Does work pay in the Republic of Slovenia?. Financial Theory and Practice, 29(4), 341-362. https://hrcak. srce.hr/5996

Državni zavod za statistiku. (2017). Rezultati Ankete o dohotku stanovništva u 2016. Statistička izvješća, 1609/2017. Zagreb: DZS.

Dušek, L., Kalíšková, K., \& Münich, D. (2013). Distribution of average, marginal and participation tax rates among Czech taxpayers: Results from a TAXBEN Model. Finance a úvěr - Czech Journal of Economics and Finance, 63(6), 474-504. Available at https://journal.fsv.cuni.cz/mag/article/show/id/1287

Galuščák, K., \& Pavel, J. (2012). Taxes and benefits: Work incentive effects of policies. Finance a úverr - Czech Journal of Economics and Finance, 62(1), 27-43. Available at https://journal.fsv. cuni.cz/mag/article/show/id/1238

Gasior, K., \& Recchia, P. (2020). The use of hypothetical household data for policy learning: Comparative tax-benefit indicators using EUROMOD HhoT. Journal of Comparative Policy Analysis: Research and Practice, 22(20), 170-189. https:// doi.org/10.1080/13876988.2019.1609784

Heckman, J. J. (1976). The common structure of statistical models of truncation, sample selection and limited dependent variables and a simple estimator for such models. Annals of Economic and Social Measurement, 5(4), 475-492. Available at http://www.nber.org/chapters/c10491

Heckman, J. J. (1979). Sample selection bias as a specification error. Econometrica, 47(1), 153-161. https://doi.org/10.2307/1912352

Immervoll, H. (2009). Minimum-income benefits in OECD countries: Policy design, effectiveness and challenges. OECD Social, Employment and Migration Working Papers, No. 100. https://doi. org/10.1787/218402763872

Immervoll, H., \& O'Donoghue C. (2002). What difference does a job make? The income consequen- 
ces of joblessness in Europe. Working Paper, No. 57. Galway: National University of Ireland, Department of Economics.

Immervoll, H., Marianna, P., \& D'Ercole, M. M. (2004). Benefit coverage rates and household typologies: Scope and limitations of tax-benefit indicators. OECD Social, Employment and Migration Working Papers, No. 20. https://doi. org/10.1787/081036000058

Jara, H. X., \& Tumino, A. (2013). Tax-benefit systems, income distribution and work incentives in the European Union. International Journal of Microsimulation, 6(1), 27-62. https://doi. org/10.34196/ijm.00076

Jara, H. X., Gasior, K., \& Makovec, M. (2019). Work incentives at the extensive and intensive margin in Europe: the role of taxes, benefits and population characteristics. Euromod Working Paper Series, EM 19/19. Available at https://www.euromod.ac.uk/sites/default/files/working-papers/ em19-19.pdf

Kump, N., Kalar, B., Majcen, B., \& Čok, M. (2020). EUROMOD country report: Slovenia 20172020. Institute for Social and Economic Research. Available at https://www.euromod.ac.uk/ sites/default/files/country-reports/year11/Y11_ CR_SI_Final.pdf

Laporšek, S., Vodopivec, M., \& Vodopivec, M. (2019). Politika isplativosti rada u Sloveniji. Revija za socijalnu politiku, 26(3), 315-337. https://doi. org/10.3935/rsp.v26i3.1582

Lietz C., \& Mantovani D. (2007). A short introduction to EUROMOD: An integrated European tax-benefit model. In O. Bargain (Ed.), Micro-simulation in action: Policy analysis in Europe using EUROMOD (Research in Labor Economics, 25) (pp. 1-16). Emerald Group. https://doi.
org/10.1016/S0147-9121(06)25001-5

Myck, M., Domitrz, A., Morawski, L., \& Semeniuk, A. (2015). Financial incentives to work in the context of a complex reform package and growing wages: The Polish experience 2005-2011. Baltic Journal of Economics, 15(2), 99-121. https://doi. org/10.1080/1406099X.2015.1124227

Navicke, J., \& Lazutka, R. (2016). Work incentives across the income distribution and for model families in Lithuania: 2005-2013. Baltic Journal of Economics, 16(2), 175-191. https://doi. org/10.1080/1406099X.2016.1205407

O’Donoghue, C. (2011). Do tax-benefit systems cause high replacement rates? A decompositional analysis using EUROMOD. LABOUR, 25(1), 126-151. https://doi.org/10.1111/j.14679914.2010.00501.x

Ranđelović, S., \& Žarković Rakić, J. (2013). Improving work incentives in Serbia: Evaluation of a tax policy reform using SRMOD. International Journal of Microsimulation, 6(1), 157-176. https://doi.org/10.34196/ijm.00080

Saez, E. (2002). Optimal income transfer programs: Intensive versus extensive labor supply responses. The Quarterly Journal of Economics, 117(3), 1039-1073. https://doi. org/10.1162/003355302760193959

Sutherland,H., \& Figari, F. (2013). EUROMOD: The European Union tax-benefit microsimulation model. International Journal of Microsimulation, 6(1), 4-26. https://doi.org/10.34196/ijm.00075

Urban, I., Bezeredi, S., \& Pezer, M. (2020). EUROMOD Country Report: Croatia 2017-2020. Institute for Social and Economic Research. Available at https://www.euromod.ac.uk/sites/ default/files/country-reports/year11/Y11_CR_ HR_Final.pdf 


\section{DODATAK}

\section{D1. Predviđanje plaća za neaktivne i nezaposlene osobe u Hrvatskoj i Sloveniji}

Za obje promatrane zemlje bruto plaće se predviđaju koristeći Heckmanov selekcijski model. Kao zavisna varijabla koristi se prirodni logaritam bruto plaće po satu, a nezavisne varijable korištene u modelu za Hrvatsku definirane su u Tablici D1. Za Sloveniju se koristi gotovo isti skup varijabli, uz iznimku da se ne koristi varijabla koja označava prebivalište u urbanom području, budući da ista ne postoji u anketnim podacima za tu zemlju.

Tablica D1.

Opis varijabli korištenih u Heckmanovom modelu za predviđanje plaće

\begin{tabular}{|c|c|}
\hline Nezavisne varijable & Opis varijabli \\
\hline Dob & Varijabla koja određuje broj godina ispitanika \\
\hline $\mathrm{dob}^{2} / 100$ & Kvadrirani iznos varijable dob podijeljen s 100 \\
\hline Obrazovanje & Varijabla koja određuje broj godina provedenih u obrazovanju \\
\hline Iskustvo & Varijabla koja određuje broj godina provedenih u radnom odnosu \\
\hline iskustvo $2 / 100$ & Kvadrat varijable radnog iskustva podijeljen s 100 \\
\hline urban & Binarna varijabla koja poprima vrijednost 1 ako osoba živi u urbanom području \\
\hline zdrav_prbl1 & $\begin{array}{l}\text { Binarna varijabla koja poprima vrijednost } 1 \text { ako je osoba bila ograničena, ali ne } \\
\text { jako, zdravstvenim tegobama u aktivnostima koje ljudi inače obavljaju }\end{array}$ \\
\hline zdrav_prbl2 & $\begin{array}{l}\text { Binarna varijabla koja poprima vrijednost } 1 \text { ako je osoba bila jako ograničena } \\
\text { zdravstvenim tegobama u aktivnostima koje ljudi inače obavljaju }\end{array}$ \\
\hline supružnik & Binarna varijabla koja poprima vrijednost 1 ako osoba ima partnera/ supružnika \\
\hline djeca00_06 & Varijabla koja određuje broj djece u dobi od 0 do 6 godina \\
\hline djeca07_14 & Varijabla koja određuje broj djece u dobi od 7 do 14 godina \\
\hline dohodak1 & $\begin{array}{l}\text { Ekvivalentni dohodak kućanstva koji se sastoji od dohotka ostalih članova } \\
\text { kućanstva od: (a) zaposlenosti i samozaposlenosti; (b) dohotka od kapitala i } \\
\text { imovine; (c) primljenih privatnih transfera. Ukupni iznos je podijeljen s } 10.000 \text {, } \\
\text { a dohodak je ekvivaliziran koristeći OECD skalu. }\end{array}$ \\
\hline dohodak2 & $\begin{array}{l}\text { Ekvivalentni dohodak kućanstva koji se sastoji od dohotka ostalih članova } \\
\text { kućanstva od: (a) mirovine; (b) naknade za nezaposlene, naknada za bolovanje } \\
\text { i rodiljni i roditeljski dopust. Ukupni iznos je podijeljen s 10.000, a dohodak je } \\
\text { ekvivaliziran koristeći OECD skalu. }\end{array}$ \\
\hline dohodak3 & $\begin{array}{l}\text { Ekvivalentni dohodak kućanstva koji se sastoji od dohotka ostalih članova } \\
\text { kućanstva od: (a) naknada za djecu; (b) naknada socijalne zaštite. Ukupni iznos } \\
\text { je podijeljen s } 10.000 \text {, a dohodak je ekvivaliziran koristeći OECD skalu. }\end{array}$ \\
\hline
\end{tabular}

Procjena modela provodi se na temelju uzorka svih fleksibilnih osoba koristeći metodu maksimalne vjerodostojnosti. Analiza se provodi, posebno za muškarce i posebno za žene, kako bi se uzele u obzir razlike između spolova, odnosno različita obilježja koja mogu utjecati na iznos predviđanih plaća. Rezultati za Hrvatsku prikazani su u Tablici D2, a za Sloveniju u Tablici D3. 
Tablica D2.

Procjena logaritma bruto plaće po satu Heckmanovim selekcijskim modelom za Hrvatsku

\begin{tabular}{|c|c|c|}
\hline & Žene & Muškarci \\
\hline & $\begin{array}{l}\text { Procijenjeni parametri } \\
\text { (standardna pogreška) }\end{array}$ & $\begin{array}{l}\text { Procijenjeni parametri } \\
\text { (standardna pogreška) }\end{array}$ \\
\hline \multicolumn{3}{|l|}{ Jednadžba plaće } \\
\hline Dob & $-0,016(0,007)^{\star \star}$ & $0,003(0,008)$ \\
\hline $\mathrm{dob}^{2}$ & $0,001(0,009)$ & $-0,011(0,009)$ \\
\hline obrazovanje & $0,099(0,003)^{\star \star \star}$ & $0,089(0,004)^{\star \star \star}$ \\
\hline iskustvo & $0,042(0,004)^{\star \star \star}$ & $0,023(0,005)^{\star \star \star}$ \\
\hline iskustvo $^{2}$ & $-0,048(0,009)^{\star \star \star}$ & $-0,026(0,009)^{\star \star \star}$ \\
\hline urban & $0,137(0,018)^{\star \star \star}$ & $0,133(0,018)^{\star \star \star}$ \\
\hline konstanta & $2,211(0,134)^{\star \star \star}$ & $2,325(0,132)^{\star \star \star}$ \\
\hline \multicolumn{3}{|l|}{ Selekcijska jednadžba } \\
\hline dob & $0,001(0,022)$ & $-0,013(0,021)$ \\
\hline $\mathrm{dob}^{2}$ & $-0,105(0,027)^{\star \star \star}$ & $-0,107(0,025)^{\star \star \star}$ \\
\hline obrazovanje & $0,126(0,012)^{\star \star \star}$ & $0,144(0,016)^{\star \star \star}$ \\
\hline iskustvo & $0,192(0,010)^{\star \star \star}$ & $0,152(0,012)^{\star \star \star}$ \\
\hline iskustvo ${ }^{2}$ & $-0,253(0,025)^{\star \star \star}$ & $-0,096(0,027)^{\star \star \star}$ \\
\hline urban & $0,198(0,067)^{\star \star \star}$ & $-0,050(0,073)$ \\
\hline zdrav_prbl1 & $-0,262(0,070)^{\star \star \star}$ & $-0,514(0,075)^{\star \star \star}$ \\
\hline zdrav_prbl2 & $-0,795(0,130)^{\star \star \star}$ & $-1,154(0,140)^{\star \star \star}$ \\
\hline supružnik & $-0,094(0,071)$ & $0,125(0,082)$ \\
\hline djeca00_06 & $-0,436(0,055)^{\star \star \star}$ & $0,179(0,073)^{\star \star}$ \\
\hline djeca07_14 & $-0,181(0,042)^{\star \star \star}$ & $0,082(0,057)$ \\
\hline dohodak1 & $-0,259(0,070)^{\star \star \star}$ & $0,160(0,097)^{\star}$ \\
\hline dohodak2 & $-0,420(0,201)^{\star \star}$ & $-0,358(0,278)$ \\
\hline dohodak3 & $-3,983(1,866)^{\star \star}$ & $-14,221(2,166)^{\star \star \star}$ \\
\hline konstanta & $-0,513(0,405)$ & $-0,265(0,411)$ \\
\hline rho & $0,662(0,054)$ & $-0,237(0,064)^{\star \star \star}$ \\
\hline sigma & $0,404(0,008)$ & $0,427(0,005)^{\star \star \star}$ \\
\hline lambda & $0,267(0,026)$ & $-0,101(0,028)^{\star \star \star}$ \\
\hline Broj opažanja & 4,032 & 4,118 \\
\hline Cenzurirana opažanja & 1,213 & 732 \\
\hline Necenzurirana opažanja & 2,819 & 3,386 \\
\hline log-vjerodostojnosti & $-2,701$ & $-3,122$ \\
\hline
\end{tabular}

Signifikantnost: ${ }^{\star} p<0,1,{ }^{\star \star} p<0,05,{ }^{\star \star \star} p<0,01$

Izvor: izračuni autora. 
Tablica D3.

Procjena logaritma bruto plaće po satu Heckmanovim selekcijskim modelom za Sloveniju

\begin{tabular}{|c|c|c|}
\hline & Žene & Muškarci \\
\hline & $\begin{array}{l}\text { Procijenjeni parametri } \\
\text { (standardna pogreška) }\end{array}$ & $\begin{array}{l}\text { Procijenjeni parametri (standardna } \\
\text { pogreška) }\end{array}$ \\
\hline \multicolumn{3}{|l|}{ Jednadžba plaće } \\
\hline dob & $-0,021(0,010)^{\star \star}$ & $-0,019(0,007)^{\star \star \star}$ \\
\hline $\mathrm{dob}^{2} / 100$ & $0,038(0,012)^{\star \star *}$ & $0,022(0,009)^{\star *}$ \\
\hline obrazovanje & $0,061(0,002)^{\star \star \star}$ & $0,064(0,002)^{\star \star \star}$ \\
\hline iskustvo & $0,020(0,004)^{\star \star \star}$ & $0,034(0,003)^{\star \star \star}$ \\
\hline iskustvo $2 / 100$ & $-0,048(0,010)^{\star \star \star}$ & $-0,066(0,009)^{\star \star \star}$ \\
\hline konstanta & $1,301(0,184)^{\star \star \star}$ & $1,438(0,134)^{\star \star \star}$ \\
\hline \multicolumn{3}{|l|}{ Selekcijska jednadžba } \\
\hline dob & $0,019(0,024)$ & $0,087(0,024)^{\star \star \star}$ \\
\hline $\mathrm{dob}^{2} / 100$ & $-0,031(0,029)$ & $-0,092(0,028)^{\star \star \star}$ \\
\hline obrazovanje & $0,078(0,007)^{\star \star \star}$ & $0,054(0,009)^{\star * *}$ \\
\hline iskustvo & $0,088(0,008)^{\star \star \star}$ & $0,013(0,010)$ \\
\hline iskustvo²/100 & $-0,192(0,021)^{\star \star \star}$ & $-0,098(0,023)^{\star \star \star}$ \\
\hline zdrav_prbl1 & $-0,197(0,072)^{\star \star \star}$ & $-0,301(0,087)^{\star \star \star}$ \\
\hline zdrav_prbl2 & $-0,524(0,141)^{\star \star \star}$ & $-0,326(0,180)^{\star}$ \\
\hline supružnik & $-0,123(0,060)^{\star \star}$ & $0,494(0,077)^{\star \star \star}$ \\
\hline djeca00_06 & $0,015(0,049)$ & $0,070(0,069)$ \\
\hline djeca07_14 & $0,056(0,040)$ & $0,055(0,061)$ \\
\hline dohodak1 & $0,774(0,304)^{\star *}$ & $1,531(0,385)^{\star \star \star}$ \\
\hline dohodak2 & $-2,067(0,887)^{\star \star}$ & $-2,457(1,024)^{\star \star}$ \\
\hline dohodak3 & $-46,973(3,757)^{\star \star \star}$ & $-63,076(4,642)^{\star \star \star}$ \\
\hline konstanta & $-0,616(0,450)$ & $-1,195(0,446)^{\star \star \star}$ \\
\hline rho & $-0,788(0,019)^{\star \star \star}$ & $-0,647(0,035)^{\star \star \star}$ \\
\hline sigma & $0,497(0,006)^{\star \star \star}$ & $0,472(0,005)^{\star \star \star}$ \\
\hline lambda & $-0,392(0,013)^{\star \star \star}$ & $-0,305(0,019)^{\star \star \star}$ \\
\hline Broj opažanja & 5,171 & 5,408 \\
\hline Cenzurirana opažanja & 667 & 414 \\
\hline Necenzurirana opažanja & 4,504 & 4,994 \\
\hline log-vjerodostojnosti & $-4,420$ & $-4,283$ \\
\hline
\end{tabular}

Signifikantnost: ${ }^{\star} p<0,1,{ }^{* \star} p<0,05,{ }^{\star \star *} p<0,01$

Izvor: izračuni autora. 


\title{
Summary
}

\section{WORK INCENTIVES IN CROATIA AND SLOVENIA: ANALYSIS USING MICROSIMULATION MODELS}

\author{
Slavko Bezeredi \\ Institute of Public Finance \\ Zagreb, Croatia
}

The paper analyzes the impact of the tax-benefit system on work incentives in Croatia and Slovenia. Unemployed and inactive persons and their hypothetical transitions to employment are considered. As the main indicator of work incentives, the participation tax rate (PTR) is estimated, as it represents a portion of additional income that is lost because taxes increase and benefits decrease in transition of a person from non-employment into employment. Unlike previous research, which was made for both countries on hypothetical data, in this paper for the first time the calculations and analysis of PTR are based on survey data, which for both countries gives a realistic picture of the situation in the field of work incentives. The analysis is carried out on data and the tax-benefit system for 2017, and the main tool used is EUROMOD, a tax-benefit microsimulation model for the EU countries. The results show that the average PTR in Croatia is of a moderate size of $31.3 \%$, while in Slovenia it is 11.3 percentage points higher. People with higher number of dependent children and those with lower level of market income obtained by other household members are more likely to have a high PTR in both countries, and in Croatia people with only primary education will also have it.

Key words: participation tax rate, work incentives, EUROMOD, Croatia, Slovenia. 